\title{
Comparative Analysis of Academic Achievement of University Students Coming from Single-Sex and Coeducational Schools: A Study in Suleyman Demirel University, Almaty, Kazakhstan
}

\author{
Ali Kocak ${ }^{1}$ \\ ${ }^{1}$ International Black Sea University, Tbilisi, Georgia \\ Correspondence: Ali Kocak, International Black Sea University, Tbilisi, Georgia. \\ Email: alikocak74@gmail.com
}

Received: April 8, 2019

Accepted: May 24, 2019

Online Published: June 1, 2019

doi: 10.23918/ijsses.v5i4p209

\begin{abstract}
Many studies (Malik \& Mirza, 2014; O’Neill, 2011; Daniels et al., 2009; Murphy, 2008; Hughes, 2007) conclude that there are numerous advantages of single-sex schooling especially for gifted, minority and economically disadvantaged students. Both boys and girls positively get affected by single-sex educational environment; while boys can express themselves comfortably in arts and theatre, and girls' performance in mathematics and science subject has significantly improved (Martin \& Beese, 2016; Leder, 2004). Both freed from opposite sex stereotype and intention of impressing opposite sex in educational process (Hughes, 2007). Past researches conclude (Murphy, 2008) that single-sex schooling also contributes positively for character building and moral development of students compared to co-educational schooling. The teachers who are the key players in educational process are varied in opinion about single-sex education (Sari, 2017; Spielhagen, 2011). The present study was carried out in the Suleyman Demirel University located in Kazakhstan. It was designed to find out the differences in academic performance of undergraduate degree programme students coming from single-sex and coeducational schools. Secondary source data was used for the analysis. Academic records of 8636 students were retrieved from the university management information system. This number of students were comprised of students who took admission from 2006-2007 academic year and graduated or left uncompleted. This number also includes students who are currently continuing the programme. Both descriptive and inferential analysis were applied. The study concludes that students from single-sex school took admission with significantly higher university entrance score. Students of single-sex schools were also granted significantly more government tuition fee waiver compared to counterparts. Hence, over the years the decrease in academic performance of single-sex students can be observed, graduated single-sex students had higher grand average compared to currently pursuing single-sex students. Moreover, even after taking admission higher score the grand average of currently pursuing single-sex students equalled (even slightly less) to students of coeducational schools. Female students from single-sex schools significantly took more admission in science and engineering disciplines compared to female students of co-educational schools.
\end{abstract}

Keywords: Single-Sex Schooling, Coeducational Schooling, Academic Performance of University Students

\section{Introduction}

After the collapse of the Soviet Union, single-sex schools, particularly high schools came into existence in Kazakhstan, which were opened by civil society institution Bilim-Innovation International Education Foundation (BIIEF). There were no such schools during the Soviet period time. After the independence of the Republic of Kazakhstan these single-sex schools were a trend as an alternative schooling offered for parents. These schools were located in almost every part of the Republic of Kazakhstan and admitted students of $6^{\text {th }}$ standard on merit-based from. These schools can be categorized as schools for gifted 
children and many of them carry names as "schools for gifted children". The foundation (BIIEF) also runs vocational co-educational high schools and coeducation international schools as an option for parents. In Kazakhstan, in the public sector, the coeducational schools are widespread and the government do not run public single-sex schools.

The university for the study was Suleyman Demirel University (SDU) which is also run by BIIEF. Due to affiliation to same group of institutions the SDU has a plenty of number of students hailing from singlesex high schools making it as the most suitable place for field study. This is a different research endeavour compared to previous studies, instead of comparing performance of school pupils' academic performance, the current study focuses on university students' academic performance. This is particularly important in the context of Kazakhstan as in this country single-sex schools are comprised by private schools for gifted children. Comparing public co-educational school students' academic performance with schools for gifted children will not be just. Academic performance is demonstrated by annual average and grand average.

Hughes (2007) in her research titled "The advantages of single-sex education" conducted in USA explores whether an educational administration should give an option for parents between co-education schooling, single-sex classroom education and single-sex schooling. The author argues that single-sex classroom or single-sex schooling is beneficial for academic improvement of school students; especially, it contributes positively to development of minority, poor and socially disadvantageous school children. The author also believes that single-sex education improves behaviour and character-building of children. She further states that in a single-sex educational environment especially in science classes there will not be gender based discrimination and prioritization of gender groups.

Hughes (2007) concludes that through single-sex education settings students will not have worries of appearance, fear of making mistake and intention to impress students of opposite sex; more time and energy will be spared for grasping the concepts and improving knowledge; which leads to less destruction and stress and further academic improvement. In Hughes' research it was also vivid that, especially in science classes, the girls in single-sex setups demonstrate better performance through participation and showing keen interest. And on the other hand, boys in the single-sex environment "are more apt to participate in areas where emotions are expressed - or in the area of fine arts; such as, drama or music (p. 9)." Which is not much possible for boys to express themselves through art in front of girls. The Author also finds that in single-sex education system both boy and girl "students' behaviour is improved in the areas of attendance, distractions, and participation, thus improving student achievement" (p.10).

Leonard Sax, the founder of the National Association for Single-Sex Public Education, believes, "The kind of learning environment that is best for boys, is not necessarily best for girls". And hence, the author believes that boys and girls both have different traits in the learning process, and special attention should be put forward in the teaching process. Richard Hawley suggests, "Physiological and psychological differences between girls and boys require different teaching techniques at different times" (as cited in Hughes, 2007). Hughes (2007) states "in single-sex classes or single-sex schools, the teacher would be able to concentrate on the learning-styles of each sex and use the styles to bring out the academic best in each student. Lessons and activities could be designed with a single-sex in mind (p. 11).” 


\section{Research Questions}

As numerous studies suggest (1) "does the single-sex education translates into more academically achieving students in Kazakhstan's context" is the main research question. (2) "Is there change in performance of single-sex students over the years" and (3) "are single-sex students more likely to graduate the university" are other pressing questions. Another interesting fact to find will be (4) "are girl students of single-sex schools more likely to take admission in science and engineering disciplines".

\section{Objectives of the Study}

These are the main objectives of the current study.

- To analyse if students from single-sex schools demonstrate higher academic achievement compared to student from coeducational students

- To develop policy suggestions for the Suleyman Demirel University, Bilim-Innovation International Education Foundation and the Government of Kazakhstan

\section{Literature Review}

Prendergast and O'Donoghue (2014) in their study titled "Influence of gender, single-sex and coeducational schooling on students' enjoyment and achievement in mathematics" focused on how gender, single-sex and co-educational system aspects can affect enjoyment of and performance in mathematics. This study took place at four schools in Ireland; two being coeducational, one girls school and one boys school. Authors shared the general perception that mathematics is male domain rather than for girls and the study aimed to find if there is real base for this perception. This study also hoped to find out if girls demonstrate better performance in mathematics in single-sex schools. It was also stated that in Ireland it is common to send children to single-sex schools and that this educational system is widespread. In this study, Aiken's two methods of scaling of mathematics as 'Enjoyment Scale' and the 'Value Scale' were applied for quantitative data collection. The authors of this study as mathematicians themselves also conducted four topics in the classes and assessed performance of students with the same examination papers to bring out correct picture of performance measurement. It was found out that male students significantly enjoy mathematics more than girls. After conducting four examinations it was found that girls outperform males, though, males enjoyed mathematics more than girls. And the study also found out that male students in single-sex school performed better in all four examinations compared to boys in coeducation schooling and in the same way girls in single-sex schooling performed better in all four examinations compared to girls in coeducational system. It can be stated that both girls and boys can focus and perform better in single-sex schooling. This can be due to girls in single-sex can be more self-confident in demonstrating skills in mathematics rather than girls in coeducation dominated by notion of mathematics is for boys. This can be also projected in findings that girls in single-sex school like mathematics more than girls in coeducational schooling.

Malik and Mirza (2014), in their research compared the academic achievements of single-sex and coeducational primary school students in Pakistan's Sindh region. Eight coeducational and eight singlesex schools were randomly chosen from pool of 128 schools in randomly selected districts, and sample size constituted 4448 students pursing 5 th standard. For the comparative analyse the board (government) 
exam results were used. The findings concluded that students from single-sex schools significantly outperformed students of coeducational schools. And moreover, girl students of single-sex schools had higher score compared to boys; hence, in coeducational school boys performed better than girls. Authors draw on socio-economic fabric of Pakistan and how single-sex schooling is important from various angle. In concluding remarks, authors emphasize policy suggestion of more single-sex schools being established by government highlighting both academic and social advantage of this schooling type. It is also recommended for Women and Gender Studies centre to document and make catalogue of research works in single-sex schooling. As part of future research suggestions, authors put ideas as adding various demographic variable beside gender and schooling type in similar researches, and this current study addresses this perspective. Authors also suggest comparing from different subjects.

One of the landmark doctorate research on the topic is by O'Neill (2011) which focused on impact of single-sex education. For two years in quasi-experimental research she studied the effect of single-sex education on academic performance in two subjects. Though not statistically significant the positive effect of single-sex environment for economically disadvantaged students of primary school students was revealed in a selected school in North Carolina. The fifth-grade students were separated into single-sex boys class, single-sex female class and coeducational setup with similar demographic fabric voluntary based. After students being taught for one year standardized test was taken from two subjects. In the coming year again new batch of classes were established with the same teachers taking teaching experiment. The study has several limitations as small sample size and different teachers being assigned to separate classes. The research reveals detailed information about history of single-sex education in USA, benefits of this educational system and reviews immensely empirical researches conducted.

\section{Methodology}

To analyse the academic achievements of the SDU students' academic records from university management system will be drawn. SDU uses university management system from 2006. From database the 8636 undergraduate students' records were brought into spreadsheet. The collected data has records of graduated, left uncompleted and currently studying students.

SDU has undergraduate, master and doctorate programmes hence in this study just records of undergraduate students will be used. The SDU was chosen as a study because this university has good number of students from single-sex schools. As such SDU belongs to BIIE Foundation, and as stated before, in Kazakhstan only BIIE Foundation runs single-sex schools. And graduates of BIIEF schools prefer and opt to pursue higher education from this particular university. MS Office Excel will be used to filter the data and inferential analysis will be performed by Minitab 17 software. ANOVA test will be applied to analyse the difference and Chi-Square test was applied to analyse the association.

\section{Hypotheses}

- $\mathrm{H}_{0} 1$ : There is no significant difference at the 5\% level of significance between SchoolingType versus GrandAverage among Graduate students

- $\mathrm{H}_{0} 2$ : There is no significant difference at the 5\% level of significance between SchoolingType versus EntranceScore among Graduate students

- $\mathrm{H}_{0} 3$ : There is no significant difference at the 5\% level of significance between SchoolingType 
versus GrandAverage among Studying students

- $\mathrm{H}_{0} 4$ : There is no significant difference at the 5\% level of significance between SchoolingType versus EntranceScore among Studying students

- $\mathrm{H}_{0} 5$ : There is no significant difference at the 5\% level of significance between SchoolingType versus Slope among students

- $\mathrm{H}_{0} 6$ : There is no significant association at 5\% level of significance between SchoolingType versus IsEngineering among Female students

- $\mathrm{H}_{0}$ 7: There is no significant association at 5\% level of significance between SchoolingType versus GrandAverage among Female students

- $\mathrm{H}_{0} 8$ : There is no significant difference at the 5\% level of significance between SchoolingType versus StudentStatus excluded Studying students

- $\mathrm{H}_{0} 9$ : There is no association difference at the 5\% level of significance between SchoolingType versus TuitionWaiver among all students

- $\mathrm{H}_{0} 10$ : There is no difference at the $5 \%$ level of significance between SchoolingType versus GrandAverage among BIIEF school students.

\section{Descriptive Analysis of the Collected Data}

Total academic record of 8636 undergraduate students were retrieved from database of university management system. These are the total number of students who were taken admission into undergraduate programmes from 2006 till 2018. Among them are the students who have graduated, currently pursuing the studies and those who have left without completing. Below is the table of variables along with their coding, and their classification, percentile analysis and scaling, and description.

Table 1: Descriptive analysis of the collected data

\begin{tabular}{|l|l|l|}
\hline $\begin{array}{l}\text { Variable and } \\
\text { Coding }\end{array}$ & $\begin{array}{l}\text { Categories, Percentile } \\
\text { Analysis and Scaling }\end{array}$ & Description \\
\hline Gender & Male $=4319(50.01 \%)$ & $\begin{array}{l}\text { Variable "Gender" indicates the gender of } \\
\text { students. Among } 8636 \text { students } 4319 \text { are male } \\
\text { and } 4314 \text { are female students, which gives } \\
\text { almost 50\% distribution. }\end{array}$ \\
\hline StudentStatus & $\begin{array}{l}\text { Graduated }=3176 \\
(36.78 \%) \\
\text { LeftUncompleting }=1373 \\
(15.9 \%)\end{array}$ & $\begin{array}{l}\text { "StudentStatus" indicates the current status of } \\
\text { the student, these are statuses as graduated, } \\
\text { and currently studying and as well } \\
\text { "LeftUncompleting" those who have left the } \\
\text { university without completing due to various } \\
\text { reasons as transferred to other institutions, or } \\
\text { expelled, or financial due, or even who took } \\
\text { academic leave. }\end{array}$ \\
\hline
\end{tabular}




\begin{tabular}{|c|c|c|}
\hline Faculty & $\begin{array}{l}\text { F_ECO }=1484(17.18 \%) \\
\text { F_ENG }=3214(37.22 \%) \\
\text { F_LAW }=1626(18.83 \%) \\
\text { F-PHIL }=2313(26.77 \%)\end{array}$ & $\begin{array}{l}\text { Suleyman Demirel University has four } \\
\text { faculties: SDU Business School (F_ECO), } \\
\text { Faculty of Engineering and Natural Sciences } \\
\text { (F_ENG), Faculty of Law and Social Sciences } \\
\text { (F_LAW) and Faculty of Education and } \\
\text { Humanities (F-PHIL). }\end{array}$ \\
\hline IsEngineering & $\begin{array}{l}\text { Engineering = } 3214 \\
(37.22 \%) \\
\text { NonEngineering }=5422 \\
(62.78)\end{array}$ & $\begin{array}{l}\text { "IsEngineering" is a variable to indicate if a } \\
\text { student is from Faculty of Engineering and } \\
\text { Natural Sciences or not. }\end{array}$ \\
\hline EntranceScore & $\begin{array}{l}\text { EntranceScore without Nill } \\
\text { value are } 7123(82.48 \%) \\
\text { EntranceScore with Nill } \\
\text { value are } 1513(17.52 \%)\end{array}$ & $\begin{array}{l}\text { The Republic of Kazakhstan every year } \\
\text { conducts nationwide university entrance } \\
\text { examination. The maximum examination } \\
\text { score is } 140 \text {. Applicants have to score } \\
\text { minimum } 50 \text { to be able to take admission in } \\
\text { undergraduate programmes in higher } \\
\text { educational institutions of Kazakhstan. Some } \\
\text { students do not have entrance score due to } \\
\text { this system has come into power later year } \\
\text { after } 2006 \text {. Students who transferred from } \\
\text { another university and who graduate from } \\
\text { professional college do not require an } \\
\text { entrance examination. }\end{array}$ \\
\hline IsBIIEFS & $\begin{array}{l}\text { BIIEFS = } 1768(20.47 \%) \\
\text { NonBIIEFS = } 6868 \\
(79.53 \%)\end{array}$ & $\begin{array}{l}\text { BIIEFS stands for "Bilim-Innovation" } \\
\text { International Educational Foundation } \\
\text { Schools. As stated earlier BIIEF Schools are } \\
\text { comprised of both single-sex and } \\
\text { coeducational schools and in Kazakhstan just } \\
\text { BIIEF has single-sex schooling system. } \\
\text { "IsBIIEFS" variable is going to indicate if } \\
\text { student has graduated from BIIEF Schools or } \\
\text { not. }\end{array}$ \\
\hline SchoolingType & $\begin{array}{l}\text { Single-sex }=1517 \\
(17.57 \%) \\
\text { Coeducational }=7119\end{array}$ & $\begin{array}{l}\text { Perhaps this is the most important variable as } \\
\text { it indicates from which schooling system - } \\
\text { single-sex or coeducation - student has }\end{array}$ \\
\hline
\end{tabular}




\begin{tabular}{|l|l|l|}
\hline & $(82.43 \%)$ & graduated. \\
\hline TuitionWaiver & Yes = 3960 (45.85\%) & $\begin{array}{l}\text { No = 4676 (54.15\%) } \\
\text { has been granted government tuition waiver } \\
\text { scholarship or not. }\end{array}$ \\
\hline GrandAverage & $\begin{array}{l}\text { GrandAverage without Nill } \\
\text { value are } 8316(96.29 \%) \\
\text { GrandAverage with Nill } \\
\text { value are 320 (3.71\%) } \\
\text { Studying and } \\
\text { GrandAverage with Nill } \\
\text { value 23 }\end{array}$ & $\begin{array}{l}\text { GrandAverage is a grand average of student } \\
\text { average for semester student studied. Some } \\
\text { students do have GrandAverage due to they } \\
\text { have started programme hence left without } \\
\text { entering any exam. There are 23 Studying } \\
\text { students with Nill value, they will be } \\
\text { eliminated in hypothesis testing. }\end{array}$ \\
\hline Slope & $\begin{array}{l}\text { Slope is the slope of the } \\
\text { linear regression line } \\
\text { representing academic } \\
\text { average for four years }\end{array}$ & $\begin{array}{l}\text { 477 graduated students do have average score } \\
\text { for every academic year. This indicates in } \\
\text { which slope value the student academic } \\
\text { performance is inclined from initial year to } \\
\text { final year. }\end{array}$ \\
\hline
\end{tabular}

\section{Findings from Inferential Analysis of the Collected Data}

Ten hypotheses are tested by MiniTab software. Each hypothesis testing along its results and interpretation are brought under one table for clear projection. 
Table 2: Hypothesis testing 1

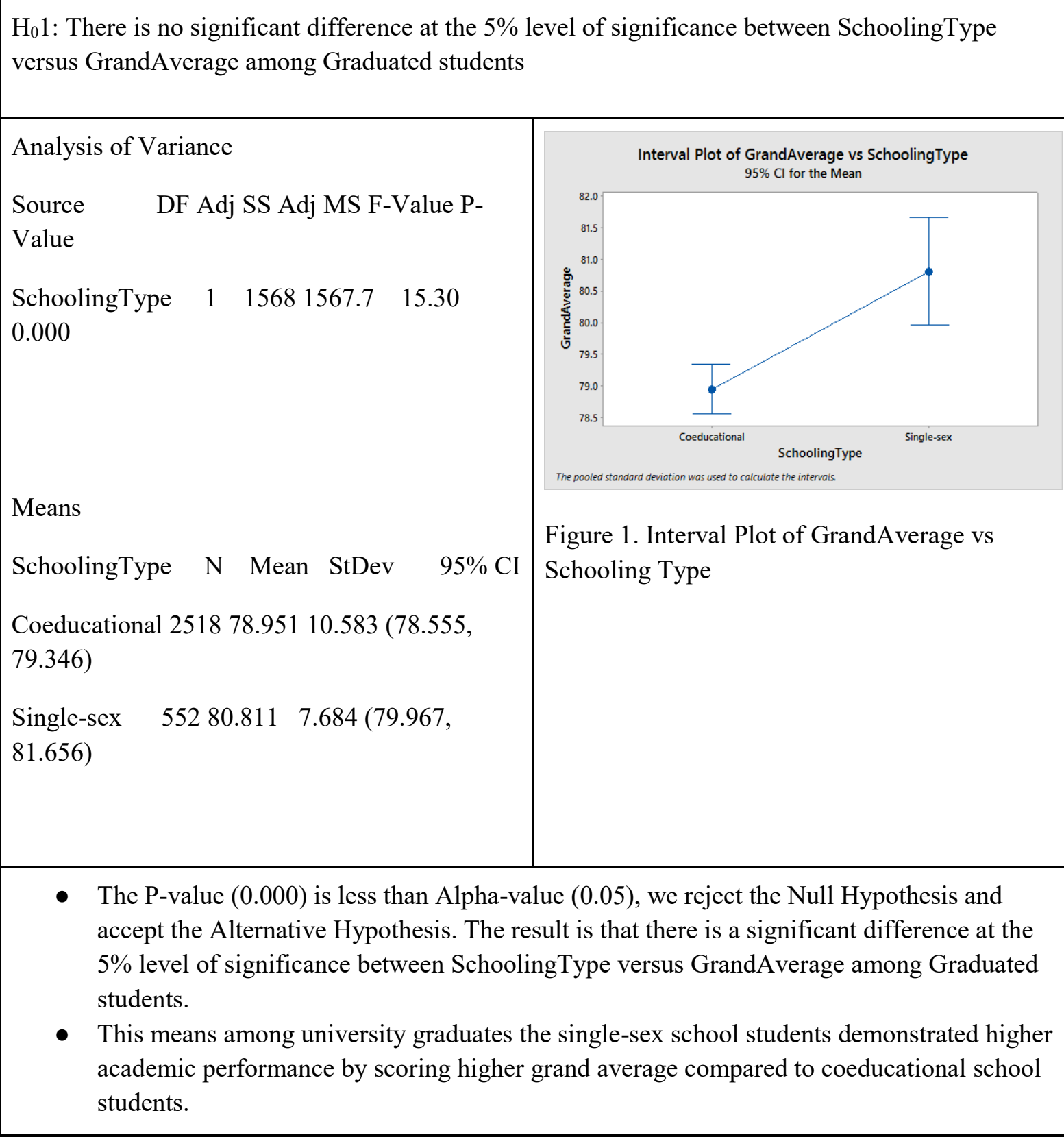


Table 3: Hypothesis testing 2

$\mathrm{H}_{0}$ 2: There is no significant difference at the $5 \%$ level of significance between SchoolingType versus EntranceScore among Graduated students

Analysis of Variance

Source DF Adj SS Adj MS F-Value P-

Value

SchoolingType $\quad 1 \quad 3664136640.5 \quad 166.96$

0.000

Means

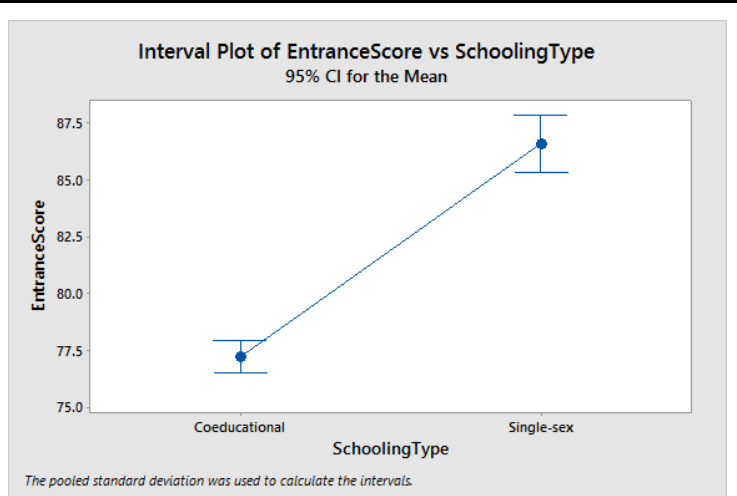

SchoolingType N Mean StDev 95\%

CI

Figure 2: Interval Plot of EntranceScore vs SchoolingType

Coeducational 175977.23415 .673 (76.542,

77.927)

Single-sex $54686.61211 .619(85.368$, 87.855)

- The P-value (0.000) is less than Alpha-value (0.05), we reject the Null Hypothesis and accept the Alternative Hypothesis. The result is that there is a significant difference at the $5 \%$ level of significance between SchoolingType versus Entrance among Graduated students.

- This means among university graduates the single-sex school students took admission with higher EntranceScore compared to coeducational school students. 
Table 4: Hypothesis testing 3

$\mathrm{H}_{0} 3$ : There is no significant difference at $5 \%$ level of significance between SchoolingType versus GrandAverage among Studying students

Analysis of Variance

Source DF Adj SS Adj MS F-Value P-

Value

SchoolingType $\quad 1 \quad 557 \quad 557.4 \quad 2.15$

0.142

Means

SchoolingType N Mean StDev 95\%

CI

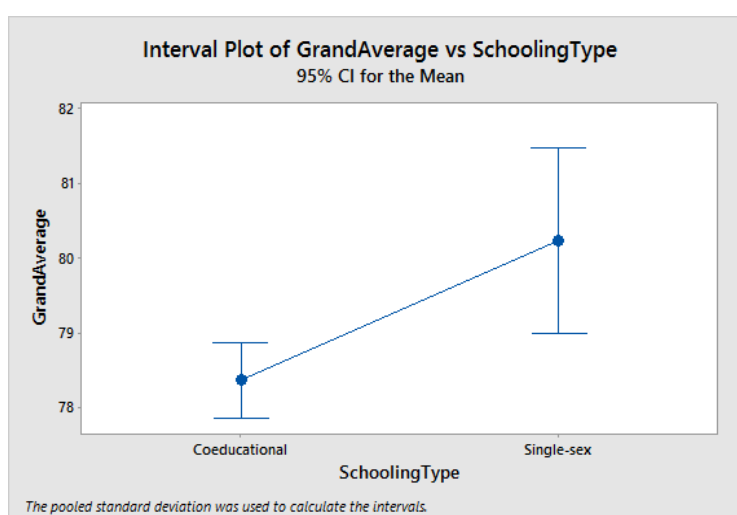

Coeducational 330773.55416 .139 (73.006,

$74.103)$

Single-sex $75772.60315 .887(71.456$

73.750)

- The P-value (0.142) is more than Alpha-value (0.05), we accept the Null Hypothesis and reject the Alternative Hypothesis. The result is that there is no significant difference at the $5 \%$ level of significance between SchoolingType versus GrandAverage among Studying students.

- This means among currently studying university students the single-sex school are not scoring higher grand average compared to coeducational school students. Moreover students from coeducational schools has slight higher Grand Average (73.55\% to $72.6 \%$ ). 
Table 5: Hypothesis testing 4

\begin{tabular}{|c|c|}
\hline Analysis of Variance & $\begin{array}{l}\text { Interval Plot of EntranceScore vs SchoolingType } \\
95 \% \text { Cl for the Mean }\end{array}$ \\
\hline $\begin{array}{l}\text { Source } \quad \text { DF Adj SS Adj MS F-Value P- } \\
\text { Value }\end{array}$ & $T$ \\
\hline $\begin{array}{llll}\text { SchoolingType } & 1 & 68106810.2 & 10.91 \\
0.001 & & & \end{array}$ & 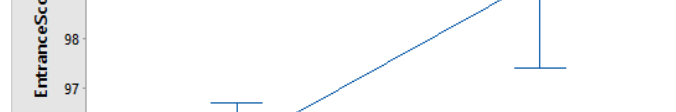 \\
\hline Means & 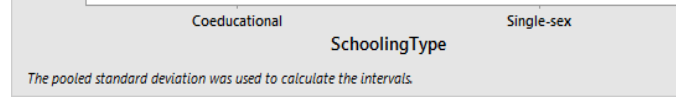 \\
\hline $\begin{array}{l}\text { SchoolingType N Mean StDev 95\% } \\
\text { CI }\end{array}$ & $\begin{array}{l}\text { Figure 4: Interval Plot of EntranceScore vs } \\
\text { SchoolingType }\end{array}$ \\
\hline $\begin{array}{l}\text { Coeducational } 319695.86026 .100 \text { (94.993, } \\
96.726)\end{array}$ & \\
\hline $\begin{array}{l}\text { Single-sex } 74999.21019 .480(97.420, \\
100.999)\end{array}$ & \\
\hline
\end{tabular}

- The P-value (0.001) is less than Alpha-value (0.05), we reject the Null Hypothesis and accept the Alternative Hypothesis. The result is that there is a significant difference at the 5\% level of significance between SchoolingType versus EntranceScore among Studying students.

- This means among currently studying university students the single-sex school students took admission with higher EntranceScore compared to coeducational school students. 
Table 6: Hypothesis testing 5

$\mathrm{H}_{0} 5$ : There is no significant difference at the $5 \%$ level of significance between SchoolingType versus Slope among students

Analysis of Variance

Source DF Adj SS Adj MS F-Value P-

Value

SchoolingType $\quad 1 \quad 1.29 \quad 1.290 \quad 0.21$

0.651

Means

SchoolingType N Mean StDev 95\% CI

Coeducational $3670.4982 .445(0.241,0.755)$

Single-sex $1100.6222 .701(0.152,1.091)$

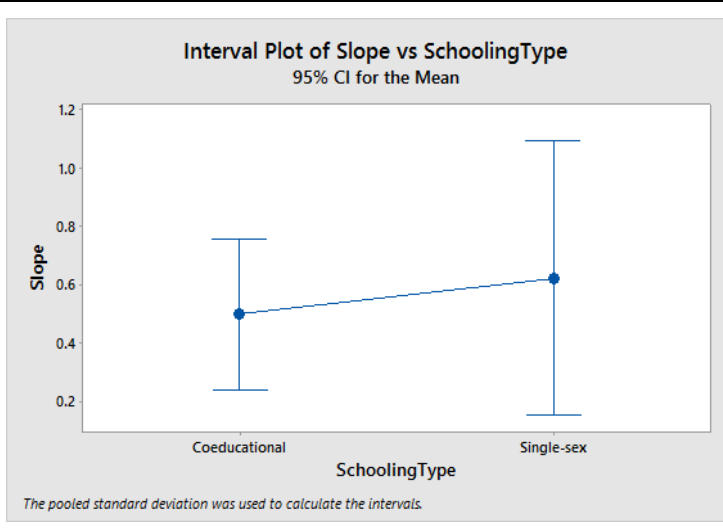

Figure 4: Interval Plot of Slope vs SchoolingType

- The P-value (0.651) is more than Alpha-value (0.05), we accept the Null Hypothesis and reject the Alternative Hypothesis. The result is that there is no significant difference at the 5\% level of significance between SchoolingType versus Slope among students.

- This means students coming from the single-sex schools have not demonstrated higher growth in academic average during four years compared to students from coeducational schools. Additionally both single-sex and coeducational students has slight demonstrated little growth from first year to final year in their academic average. 
Table 7: Hypothesis testing 6

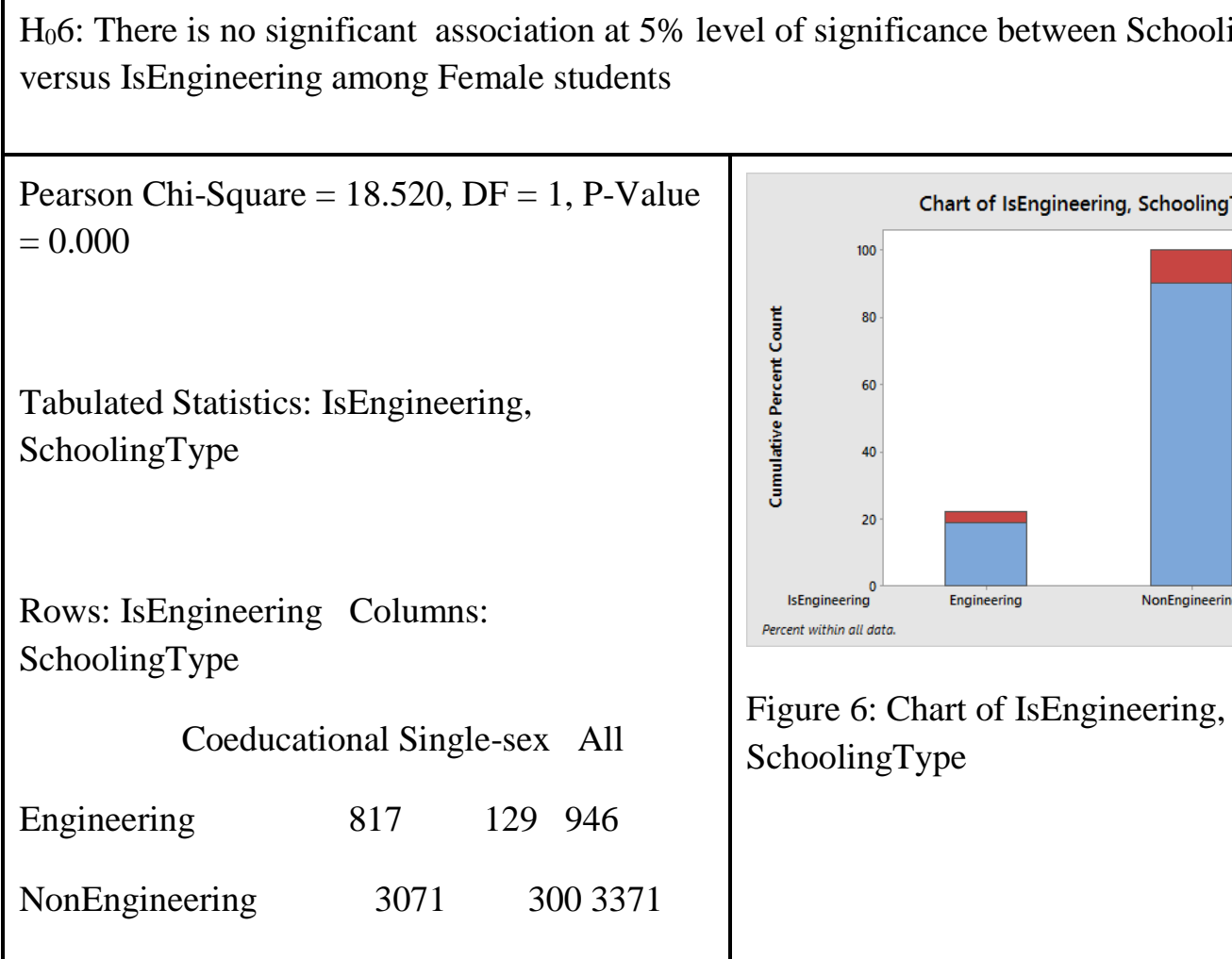

- The P-value (0.000) is less than Alpha-value (0.05), we reject the Null Hypothesis and accept the Alternative Hypothesis. The result is that there is a significant association at $5 \%$ level of significance between SchoolingType versus IsEngineering among Female students.

- This means among female students the single-sex school students comparatively took more admission in Faculty of Engineering and Natural Sciences compared to coeducational school students. 
Table 8: Hypothesis testing 7 $\mathrm{H}_{0} 7$ : There is no significant association at $5 \%$ level of significance between SchoolingType versus
GrandAverage among Female students

Analysis of Variance

Source $\quad$ DF Adj SS Adj MS F-Value P-

Value

SchoolingType $\quad 1 \quad 37003699.9 \quad 20.64$

0.000

Means

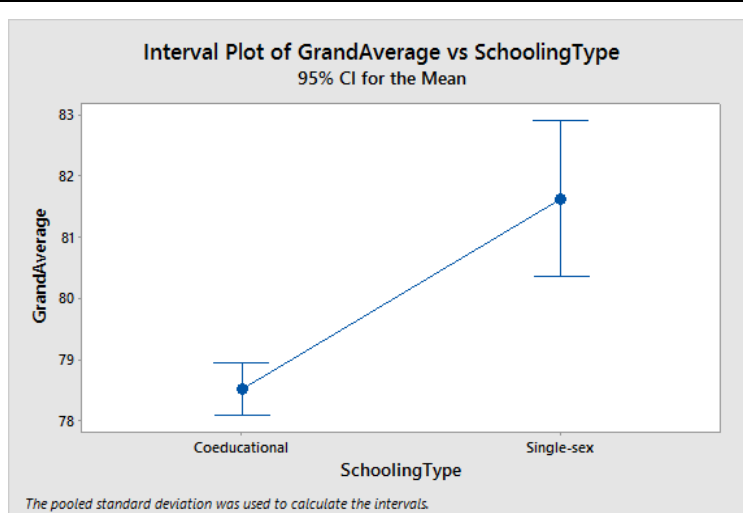

SchoolingType N Mean StDev 95\% CI

Coeducational 376178.53413 .567 (78.106,

Figure 7: Interval Plot of GrandAverage vs SchoolingType

78.962)

Single-sex $42881.63711 .698(80.368$, 82.906)

- The P-value (0.000) is less than Alpha-value (0.05), we reject the Null Hypothesis and accept the Alternative Hypothesis. The result is that there is a significant difference at the $5 \%$ level of significance between SchoolingType versus GrandAverage among Female students.

- This means the female students from single-sex school scored higher grand average compared to female students from coeducational schools. 
Figure 9: Hypothesis testing 8

$\mathrm{H}_{0} 8$ : There is no significant difference at the $5 \%$ level of significance between SchoolingType versus StudentStatus excluded Studying students

Pearson Chi-Square $=4.146, \mathrm{DF}=1, \mathrm{P}-$ Value $=$ 0.042

Rows: StudentStatus Columns: SchoolingType Coeducational Single-sex All

Graduated $2624 \quad 552 \quad 3176$ $69.20 \quad 72.92 \quad 69.82$

LeftUncompleting $\quad 1168 \quad 205$ 1373

$30.80 \quad 27.08 \quad 30.18$

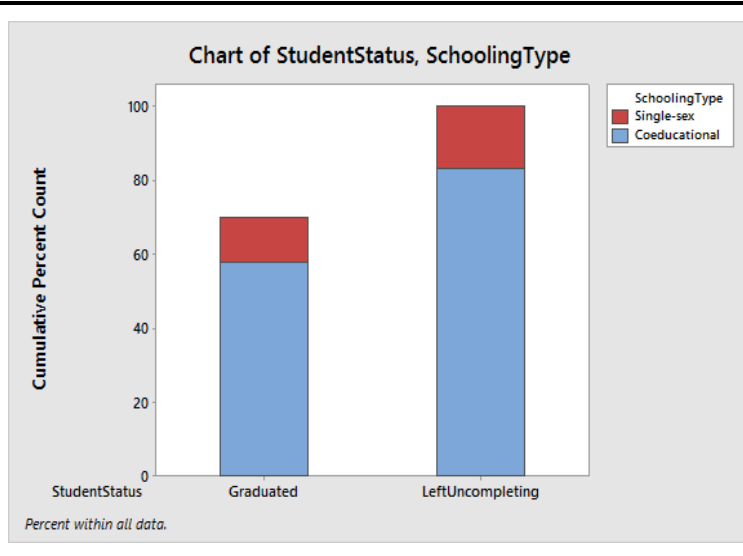

Figure 8: Chart of StudentStatus, SchoolingType

- The P-value (0.042) is less than Alpha-value (0.05), we reject the Null Hypothesis and accept the Alternative Hypothesis. The result is that there is a significant difference at the 5\% level of significance between SchoolingType versus StudentStatus excluding Studying students.

- This means the single-sex school students are more likely to graduate the university compared to coeducational school students. 
Table 10: Hypothesis testing 9

$\mathrm{H}_{0} 9$ : There is no association difference at the $5 \%$ level of significance between SchoolingType versus TuitionWaiver among all students.

Pearson Chi-Square $=70.917, \mathrm{DF}=1, \mathrm{P}-$ Value $=0.000$

Tabulated Statistics: SchoolingType, TuitionWaiver

Rows: SchoolingType Columns:

TuitionWaiver

$\begin{array}{rrrr}\text { No } & \text { Yes } & \text { All } & \\ \text { Coeducational } & 4003 & 3116 & 7119\end{array}$

56.2343 .77100 .00

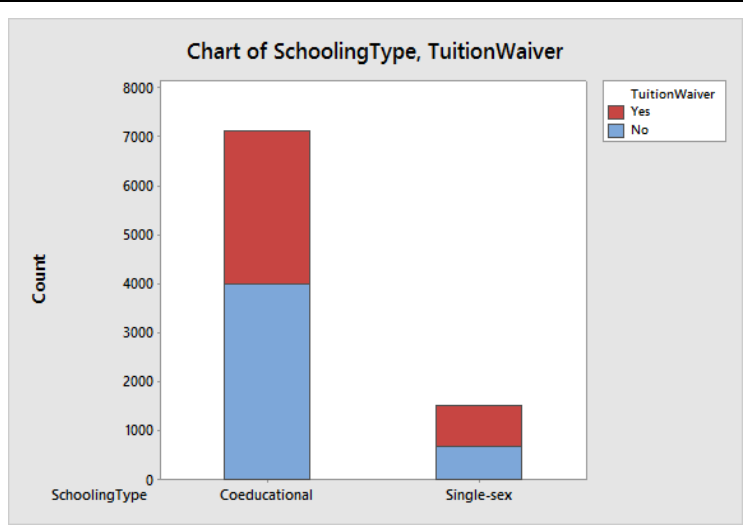

Figure 9: Chart of SchoolingType, TuitionWaiver

Single-sex $\quad 673 \quad 844 \quad 1517$

44.3655 .64100 .00

- The P-value (0.000) is less than Alpha-value (0.05), we reject the Null Hypothesis and accept the Alternative Hypothesis. The result is that there is a significant association at $5 \%$ level of significance between SchoolingType versus TuitionWaiver among all students.

- This means the students from single-sex schools have been granted more government tuition waiver scholarship comparatively to students from coeducational schools. 
Figure 11: Hypothesis testing 10

\begin{tabular}{|c|c|}
\hline Analysis of Variance & $\begin{array}{l}\text { Interval Plot of GrandAverage vs SchoolingType } \\
95 \% \mathrm{Cl} \text { for the Mean }\end{array}$ \\
\hline Source $\quad$ DF Adj SS Adj MS F-Value P- & $\tau$ \\
\hline Value & \\
\hline $\begin{array}{llll}\text { SchoolingType } & 1 & 56085608.1 & 19.30 \\
0.000 & & & \end{array}$ & 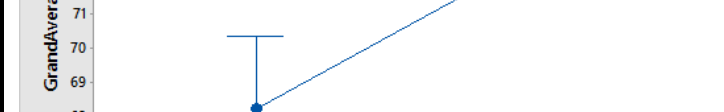 \\
\hline Means & \begin{tabular}{l|l}
67 & \\
66
\end{tabular} \\
\hline SchoolingType N Mean StDev 95\% CI & 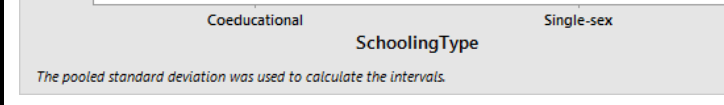 \\
\hline $\begin{array}{l}\text { Coeducational } 244 \quad 68.21 \quad 20.30(66.07, \\
70.35)\end{array}$ & $\begin{array}{l}\text { Figure 10: Interval Plot of GrandAverage vs } \\
\text { SchoolingType }\end{array}$ \\
\hline $\begin{array}{l}\text { Single-sex } \quad 150173.37516 .459(72.513, \\
74.238)\end{array}$ & \\
\hline \multicolumn{2}{|c|}{$\begin{array}{l}\text { - The P-value }(0.000) \text { is less than Alpha-value }(0.05) \text {, we reject the Null Hypothesis and } \\
\text { accept the Alternative Hypothesis. The result is that there is a significant difference at the } \\
5 \% \text { level of significance between SchoolingType versus GrandAverage among BIIEF } \\
\text { school students. } \\
\text { - This means among BIIEDF Schools students the single-sex school students have scored } \\
\text { higher grand average comparatively to coeducational school students. }\end{array}$} \\
\hline
\end{tabular}

\section{Conclusion}

By analysing the data of graduated students, it was found that students from single-sex schools took admission with higher university entrance score and achieved higher academic performance compared to coeducational students. By analysing the data of currently studying students it was found that students from single-sex schools took admission with higher university entrance score and however they have not achieved higher academic performance compared to coeducational students. Moreover, students from coeducational schools have slight better academic achievement (73.55\% to $72.6 \%$ ). It can be concluded that single-sex students those already graduated has demonstrated better academic achievement compared with current ones.

Students coming from the single-sex schools have not demonstrated higher growth in year-on-year academic average during four years compared to students from coeducational schools. That is single-sex 
students are less progressive compared to coeducational students in their initial academic performance over the four years. Additionally, both single-sex and coeducational students has demonstrated slightly little growth from first year to final year in their academic average.

It is argued that single-sex schooling provides better platform for female students to opt so-called male subjects as engineering, science and mathematics, and believed leads better academic performance. By analysing the female students' data, it was found that female students from single-sex schools took more admission in engineering, science and mathematics and as well demonstrated higher academic achievement compared female students from coeducational schools.

By analysing graduation level of students, it was found that single-sex students are more likely to graduate university without leaving uncompleted. Republic of Kazakhstan provides tuition waiver scholarship for best performing students from nationwide university entrance examination score. And students from single-sex schools were awarded more grant compared to coeducational school students. This means the students from single-sex schools have been granted more government tuition waiver scholarship comparatively to students from coeducational schools. If we see just analyse data among BIIEF Schools students the single-sex school students have scored higher grand average comparatively to coeducational school students.

\section{Discussion and Suggestions}

In the findings it can be observed that students of single-sex school have taken admission with higher university examination and granted more government tuition waiver scholarship. As a policy suggestion the number of single-sex schools can be increased by BIIEF and government also can take up pilot singlesex school projects.

Single-sex school students also demonstrated higher grand average hence lately this is not the case. BIIEF administration should take into consideration and perform study why current students from its single-sex schools are not demonstrating better achievement event after taking admission with higher entrance score.

And plus year-on-year progress of single-sex students are also lower compared to counterparts. SDU administration can take up research and review why single-sex school students do not perform their full potentials. It is positive sign to see that single-sex schools positively effect upon girl students to take admission in engineering and science streams. Government and BIIEF can consider in establishing more girls' schools. As a future study comparative analysis of post university life of the students can be studied. And as well the study on parents' expectation from single-sex schools also will be an interesting research.

\section{References}

Brutsaert, H. (2006). Gender-role identity and perceived peer group acceptance among early adolescents in Belgian mixed and single-sex schools. Gender and Education, 18(6), November 2006, 635649. doi: 10.1080/09540250600980204.

Cable, K. E., \& Spradlin, T. E. (2008). Single-Sex education in the 21st century. New York: Doubleday. Ganley, C. M., Vasilyeva, M., \& Dulaney, A. (2014). Spatial ability mediates the gender difference in middle school students' science performance. Child Development, 85(4), 1419-1432. 
Gurian, M., Stevens, K., \& Daniels, P. (2009). Single-Sex classrooms are succeeding. In Michael Gurian (Ed.) Successful Single-Sex Classrooms: A practical guide to teaching boys \& girls separately. Jossey-Bass.

Hughes, T. A. (2006). The advantages of single-sex education. National Forum of Educational Administration and Supervision Journal, 23(2), 5-15.

Leder, G. (2004). Gender differences among gifted students: Contemporary views. High Ability Studies, 15(1). Carfax Publishing.

Lee, V. E., \& Bryk, A. S. (1986). Effects of single-sex secondary schools on student achievement and attitudes. Journal of Educational Psychology, 78, 381-395.

Lee, V. E., \& Marks, H. M. (1990). Sustained effects of the single-sex secondary school experience on attitudes, Behaviors, and values in college. Journal of Educational Psychology, 82(3), 578592.

Mael, F., Alonso, A., Gibson, D., Rogers, K., \& Smith, M. (2005). Single-sex versus coeducational schooling: A systematic review. U.S. Department of Education Office of Planning, Evaluation and Policy Development: Doc \# 2005-01.

Mael, F., Smith, M., Alonso, A., Rogers, K., \& Gibson, D. (2004). Theoretical arguments for and against single-sex schools: A critical analysis of the explanations. United States Department of Education.

Malik, R., \& Mirza, M. (2014). Gender differential academic achievement of students in single-sex and coeducational primary schools in Pakistan. Bulletin of Education and Research, 36(1), 1-14.

Martin, J., \& Beese, J. A. (2016). Pink is for girls: sugar and spice and everything nice-A case of single-sex education. Journal of Cases in Educational Leadership, 19(4), 86-101. doi: $10.1177 / 1555458916664762$.

Murphy, M. (2008). Moral development in single-sex schools: A review of the research. Proceedings of the 34th Annual Conference of the Association for Moral Education. University of Notre Dame.

Murphy, P., \& Ivinson, G. (2000). Construction of knowledge, social identities and pedagogy in single and mixed sex groupings. Proceedings of the Annual Meeting of the American Educational Research Association. New Orleans.

Prendergast, M., \& O’Donoghue, J. (2014). Influence of gender, single-sex and co-educational schooling on students' enjoyment and achievement in mathematics. International Journal of Mathematical Education in Science and Technology, 45(8). 1115-1130. doi: 10.1080/0020739X.2014.904530

Sari, M. (2017). Teachers' Views on Co-education: Co-education or Single-sex Education? Acta Didactica Napocensia, 10(3), 35-44.

Sax, L. (2005). Why gender matters: What parents and teachers need to know about the emerging science of sex differences. New York: Doubleday.

Spielhagen, F. R. (2011). "It all depends...": Middle School Teachers Evaluate Single-Sex Classes. In Micki M. Caskey (Ed.), RMLE Online Research in Middle Level Education, 34(7).

Spielhofer, T., O’Donnell, L., Bruton, T., Schagen, S., \& Schagen, I. (2002). The impact of school size and single-sex education on performance. LGA Research Report, 33. Slough: National Foundation for Educational Research. 